\title{
Characterization of Ammonia Removal from Municipal Wastewater Using Microwave Energy: Batch Experiment
}

\author{
Fahid K. J. Rabah ${ }^{1} \&$ Mohamad S. Darwish ${ }^{1}$ \\ ${ }^{1}$ Faculty of Civil and Environmental Engineering, the Islamic University-Gaza, Palestine \\ Correspondence: Fahid K. J. Rabah, Faculty of Civil and Environmental Engineering, the Islamic \\ University-Gaza, Rimal, Palestine. Tel: 97-259-952-8047. E-mail: frabah@iugaza.edu.ps
}

Received: November 7, 2012 Accepted: December 8, 2012 Online Published: December 12, 2012

doi:10.5539/enrr.v3n1p42

URL: http://dx.doi.org/10.5539/enrr.v3n1p42

\begin{abstract}
This study investigates the characteristics of ammonia removal from municipal wastewater using microwave radiation (MW). Synthetic and real wastewater samples were heated in batch reactors by MW radiation and ammonia removal efficiency was tested under variable conditions. The effects of initial ammonia concentration, $\mathrm{pH}$, and radiation time on ammonia removal efficiency were investigated. Radiation time and $\mathrm{pH}$ showed significant influence on the removal of ammonia nitrogen with lower influence of the initial ammonia concentration. The highest ammonia removal efficiency achieved was $91.1 \pm 0.8 \%$ and $90.5 \pm 1.2 \%$ for synthetic and real wastewaters, respectively. The highest efficiency in both cases was achieved at a $\mathrm{pH}$ of 11 with 4 minutes of MW radiation. Comparing the results of this study with the work of others, it was found that ammonia removal efficiency from municipal wastewater that normally has low initial ammonia concentration is less than its removal efficiency from industrial wastewater that has initial ammonia concentrations in the range of $500-12000 \mathrm{mg} \mathrm{NH} \mathrm{N}_{3}-\mathrm{N} / \mathrm{L}$. It is concluded from this study that $\mathrm{MW}$ radiation is an effective method for the removal of ammonia nitrogen from municipal wastewater.
\end{abstract}

Keywords: microwave radiation, ammonia nitrogen, $\mathrm{pH}$, municipal wastewater, heating

\section{Introduction}

Ammonia nitrogen is a hazardous contaminant that should be removed from wastewater before reuse or disposal to the environment. The typical ammonia nitrogen concentration in the raw municipal wastewater is in the range of 30 to $100 \mathrm{mg} \mathrm{NH}$ - $\mathrm{N} / \mathrm{L}$ (CMWU, 2010). Globally, reclaimed wastewater quality standards specify the maximum allowable ammonia concentration according to the reuse purposes. For example, the Jordanian standards limit the maximum ammonia concentration to $5 \mathrm{mg} \mathrm{NH}_{3}-\mathrm{N} / \mathrm{L}$ for wastewater reuse in recharge to groundwater (JSIM, 2006). Several technologies are applied to remove ammonia nitrogen from wastewater, such as biological processes (Holman \& Wareham, 2005), ammonia-stripping (Guštin \& Logar, 2011), chemical precipitation (Huang et al., 2012) and ion exchange (Jorgensen \& Weatherley, 2003). Biological processes are the most commonly used process for ammonia removal from municipal wastewater. However, this process requires high capital and running costs. Moreover, this process is highly sensitive to environmental conditions such as temperature and $\mathrm{pH}$. Ammonia stripping requires high energy supply in running the stripping towers (Lin et al., 2009). Chemical precipitation is effective to some extent, but it is based on adding chemical reagents, which may produce other pollutants in water (Huang et al., 2012).

Microwave (MW) radiation is a promising technique for wastewater treatment that had attracted a number of researchers to explore its unknown effects on wastewater pollutants. Lin et al. (2009) used MW radiation to remove high-concentrated ammonia nitrogen from both simulated and real industrial wastewater samples through a bench-scale study. The concentrations ranged from $500 \mathrm{mg} \mathrm{NH}$ - $\mathrm{N} / \mathrm{L}$ to $12,000 \mathrm{mg} \mathrm{NH} 3-\mathrm{N} / \mathrm{L}$. They investigated four affecting factors: radiation time, initial $\mathrm{pH}$, initial ammonia concentration and aeration. The experiment results showed that higher $\mathrm{pH}$ and $\mathrm{MW}$ radiation time resulted in larger ammonia removal, with minute effect of aeration. They achieved a removal efficiency of $98.2 \%$ in 3 min of radiation with initial concentration of $500 \mathrm{mg} \mathrm{NH}-\mathrm{N} / \mathrm{L}$. Lin et al. (2009) explained in details the mechanism of ammonia removal from wastewater which was mainly attributed to the generated heat in the solution due to MW radiation. They stated that by increasing the MW radiation, the solution temperature becomes higher and the random water molecular motion increases. This stimulates the escape of molecular ammonia from solution by volatilizations. 
Zieliński et al. (2013) studied the possibilities for improving wastewater treatment by applying MW radiation, compared to convective heating of trickling filters. They delivered the microwaves to the biofilm in a continuous and intermittent way, having temperatures of $20,25,35$ and $40^{\circ} \mathrm{C}$. The authors found that the presence of organic compounds in the continuous influent exposed to MW resulted in $10 \%$ higher efficiency and $20 \%$ higher rate of nitrification compared to intermittent MW radiation and convective heating. In addition, they observed that the absence of organic carbon in the influent induced a significant increase in ammonium oxidation efficiency at $20-35^{\circ} \mathrm{C}$.

Yang et al. (2009) explored an advanced oxidation process based on sulfate radical $\mathrm{SO}_{4}{ }^{2-}$ to degrade organic pollutants in wastewater. They used a MW-activated persulfate oxidation with or without active carbon. The experiment were conducted to examine whether MW heating is an effective method to activate persulfate and then to decompose biorefractory organic compounds in wastewater by using an Azo Dye Acid Orange 7 (AO7) (up to $1,000 \mathrm{mg} / \mathrm{L}$ ) as a model compound. It was found that AO7 was completely decolorized within 5-7 min. By adding $1.0 \mathrm{~g} / \mathrm{L}$ of active carbon as catalyst, $100 \%$ decolorization of AO7 $(500 \mathrm{mg} / \mathrm{L})$ was achieved within 3 min.

Jothiramalingam et al. (2010) used MW heating for the stabilization of industrial wastewater sludge and reported significant increase of sludge stabilization efficiency compared to conventional heating by heat exchangers. Eskicioglu et al. (2009) investigated the enhancement of thermophilic anaerobic digestion of thickened waste activated sludge by combined microwave heating and alkaline pretreatment. They found that methane production was increased by $27 \%$ due to MW heating compared to traditional heating methods.

After literature review, it was found that the use of MW radiation in removing ammonia from municipal wastewater is not yet investigated. Hence, this study was initiated to fill this gap by determining the characteristics of this process and to specify its optimum operating conditions.

\section{Materials and Methods}

Figure 1 shows a schematic diagram of the experimental apparatus. A domestic microwave oven $(700 \mathrm{~W}, 2450$ MHz, Dura brand XB2316, UK) with multiple power settings was used as the source of the MW radiation. A hole was drilled on its top cover, with copper pipe inserted to prevent MW emission (Yang et al., 2009).

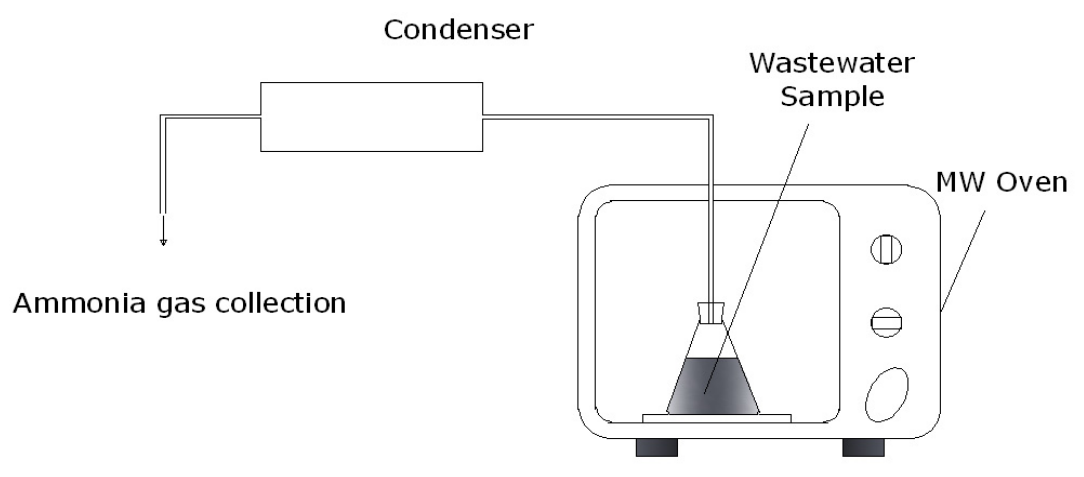

Figure 1. Schematic diagram of the experimental apparatus

To make sure that there was not any harmful radiation leakage, the radiation exposure rate of the MW oven was tested before starting experiments, using electric and magnetic field measurement device (EMR-21C, Safety Test Solutions, Germany), and it was completely safe.

A 250-ml Erlenmeyer flask containing $100 \mathrm{ml}$ of wastewater was placed in the oven and radiated under different conditions. The flask was connected to a condensing system. The temperature was measured by a thermometer and the final concentration of the ammonia nitrogen was measured using Nessler standard method (APHA, AWWA, \& WEF, 1989).

Synthetic wastewater solution was prepared with ammonium chloride $(99.5 \%$, analytical reagent, HiMedia Laboratories, Mumbai, India) and distilled water. The initial $\mathrm{pH}$ of the solution was adjusted using sodium hydroxide solution ( $\mathrm{NaOH}, 2.0 \mathrm{~mol} / \mathrm{L}, 97.5 \%$, Chemie, Mumbai, India).

After heating each sample, the volume of wastewater slightly decreased due to evaporation of water. Thus, after 
heating each sample, the volume was adjusted with deionized water, using a 100-ml Erlenmeyer flask, to keep the same initial volume of the samples. In all experiments, for statistical purposes, each condition was tested 5 times and an average value was reported together with its corresponding standard deviation.

As a comparison, the same experiment was applied on real municipal wastewater samples, which were obtained from Gaza Wastewater Treatment Plant. The removal efficiencies of ammonia nitrogen were compared with those resulted from synthetic wastewater.

\section{Results and Discussion}

In order to achieve the best removal of ammonia nitrogen from municipal wastewater, the affecting factors, including initial ammonia concentration, $\mathrm{pH}$, and radiation time were investigated. In this research, no aeration was applied, since it has a minute effect on ammonia nitrogen removal as illustrated elsewhere (Lin et al., 2009).

\subsection{Effect of Initial Ammonia Concentration}

In this experiment, six initial ammonia concentrations were tested $\left(25,40,55,70,85\right.$, and $\left.100 \mathrm{mg} \mathrm{NH}_{3}-\mathrm{N} / \mathrm{l}\right)$ at $\mathrm{pH}$ values of 9,10 , and 11 and at radiation times in the range of 1 to 5 minutes. Figure 2 represents the effect of initial ammonia concentration on residual ammonia concentration at $\mathrm{pH}=11$ and radiation times of $1,2,3,4$, and 5 minutes.

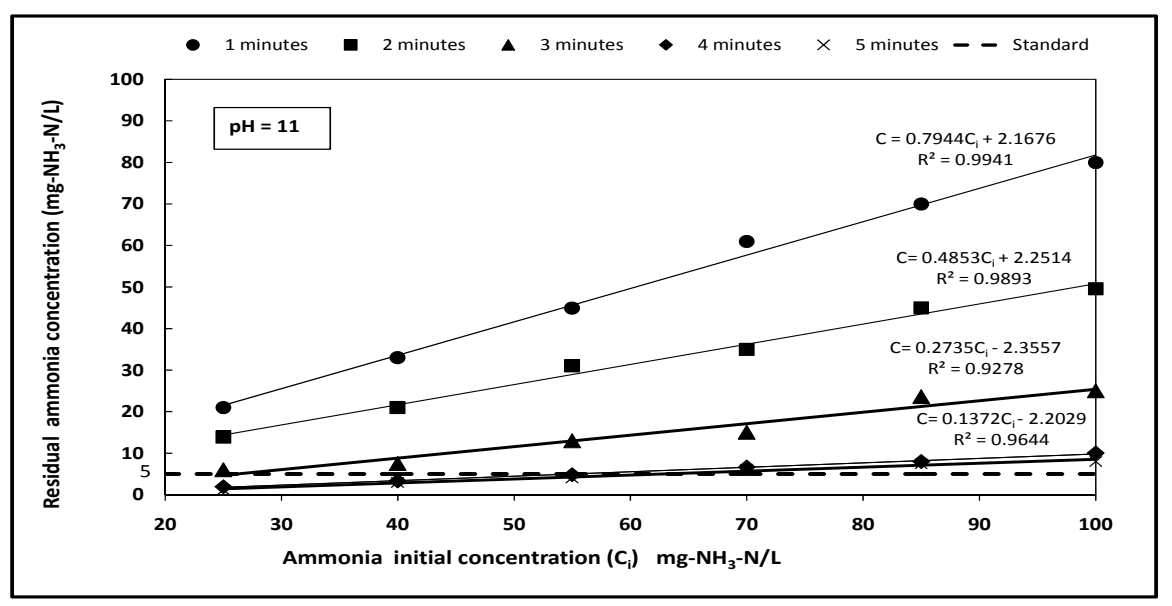

Figure 2. Effect of initial ammonia concentration on residual ammonia concentration $(\mathrm{pH}=11)$

It is interpreted from the figure that the value of the residual ammonia concentration $(\mathrm{C})$ increased linearly with the increase of initial ammonia concentration $\left(\mathrm{C}_{\mathrm{i}}\right)$ as illustrated by the regression equations presented on Figure 2 . For example (at a pH value of 11 and a radiation time of 3 minutes), when $\left(\mathrm{C}_{\mathrm{i}}\right)$ was $25 \mathrm{mg} \mathrm{NH}-\mathrm{N} / 1$ (C) was 6.2 $\mathrm{mg} \mathrm{NH}-\mathrm{N} / \mathrm{l}$, and when $\left(\mathrm{C}_{\mathrm{i}}\right)$ was $85 \mathrm{mgNH}_{3}-\mathrm{N} / \mathrm{l}(\mathrm{C})$ was $23.5 \mathrm{mgNH}_{3}-\mathrm{N} / \mathrm{l}$. The same behavior was detected for other radiation times (i.e. 1, 2, 3, and 5) and other values of $\mathrm{pH}$ (i.e. 9 and 10). The benefit of this finding is the ability to determine the initial ammonia concentrations at which a specific residual ammonia concentration can be achieved. For example, a maximum residual ammonia concentration of $5 \mathrm{mg} \mathrm{NH}-\mathrm{N} / 1$ is required by the Jordanian standards so that the treated wastewater can be recharged to groundwater (Jordanian Standards, 2006). In this work, as interpreted from Figure 2, a residual ammonia concentration of $5 \mathrm{mg} \mathrm{NH}_{3}-\mathrm{N} / 1$ is achieved when the initial ammonia concentration was $55 \mathrm{mg} \mathrm{NH}-\mathrm{N} / 1$ or less (at a $\mathrm{pH}$ value of 11 and a radiation time of 4 minutes).

Another finding of this part of the experiment is that the ammonia removal percent ( $r$ ) was not significantly affected by the value of the initial concentration $\left(\mathrm{C}_{\mathrm{i}}\right)$. The linear correlation between $(\mathrm{r})$ and $\left(\mathrm{C}_{\mathrm{i}}\right)$ is indicated by the regression equations given in Figure 3 for radiation times of 1, 2, 3, 4, and 5 minutes. The slope of these lines are close to zero $(0.0285,0.0655,-0.0567,-0.0604,-0.0426)$ and the lines are almost parallel to the $\mathrm{x}$-axis. This verifies that the initial concentration of ammonia has minor effect on ammonia removal percent $(r)$ for the $\left(\mathrm{C}_{\mathrm{i}}\right)$ concentrations range studied in this work. For example (at $\mathrm{pH}$ of 11 and radiation time of 4 minutes), when the initial concentrations were $25,40,55,70,85$, and $100 \mathrm{mgNH}_{4}-\mathrm{N} / 1$, the removal percents were $92.2,91.70,91.3$, $90.5,90.6$, and $90.1 \%$, respectively. The average removal rate $\left(\mathrm{r}_{\text {average }}\right)$ in this case is $91.1 \%$ with a standard 
deviation (STD) of $\pm 0.8 \%$ (small deviation around $\mathrm{r}_{\text {average }}$ ). Similar results were obtained for other radiation times as given in Table 1 and as interpreted from Figure 3.

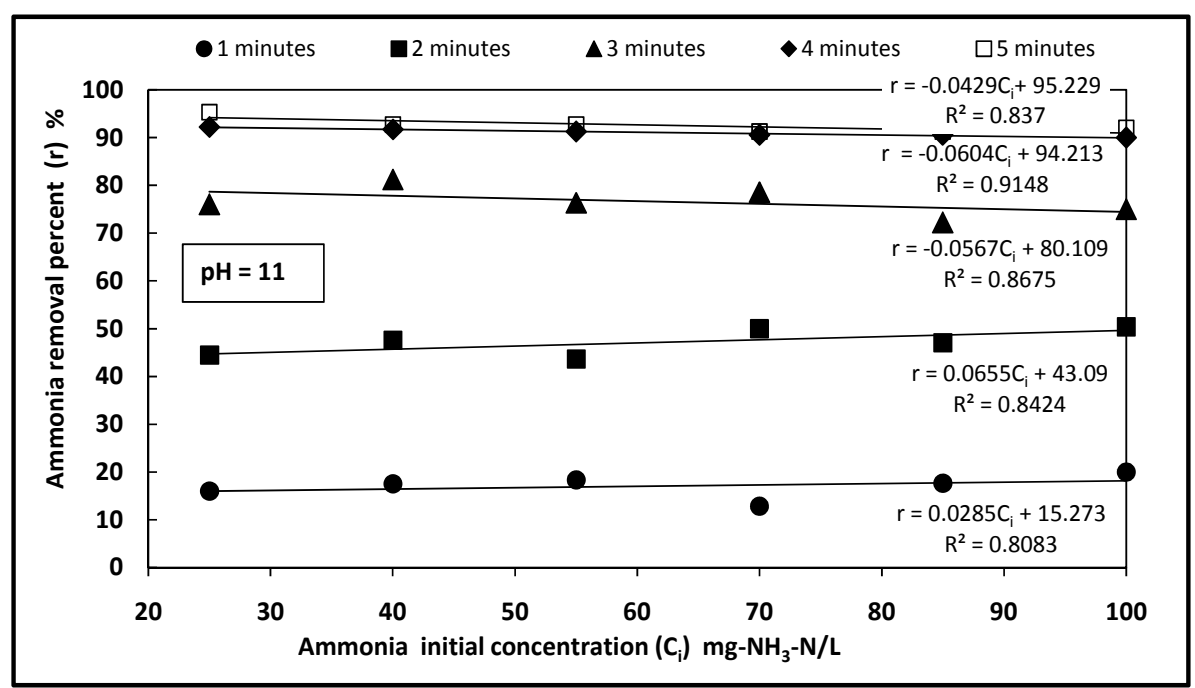

Figure 3. Effect of initial ammonia concentration on ammonia removal percent at $\mathrm{pH} 11$

It should be clarified at this point that there is no contradiction that $\mathrm{C}_{\mathrm{i}}$ affects $\mathrm{C}$ in direct proportion (as illustrated by Figure 2) while it doesn't significantly affect (r) (as illustrated by Figure 3). This can be explained by looking at the ammonia removal percent formula:

$$
r=\frac{C_{i}-C}{C_{i}} \times 100
$$

What keeps ( $r$ ) almost constant is that when $C_{i}$ increases, $C$ increases proportionally, as illustrated above, and the right hand term of the formula doesn't significantly change. Similar conclusion was reached by Cheung et al. (1997) while commenting on mass transfer of ammonia from liquid to air in their experiments on ammonia stripping from landfill leachate.

Hence, the main conclusion of this part of the experiment is that for each radiation time $(\mathrm{t})$ and $\mathrm{pH}$ value there is an average removal percent $\left(\mathrm{r}_{\text {average }}\right)$ regardless of the value of the initial ammonia concentration. The main factors that affect $(\mathrm{r})$ are the $\mathrm{pH}$ value and the radiation time rather than $\mathrm{C}_{\mathrm{i}}$ as illustrated by Figure 3 and Table 1 .

Table 1. Ammonia average removal percent for initial concentrations in the range of $25-100 \mathrm{mg} / \mathrm{L}$ at $\mathrm{pH}=11$ and radiation times in the range of 1 to 5 minutes

\begin{tabular}{cccccc}
\hline \multirow{2}{*}{ Item } & \multicolumn{5}{c}{ Radiation time (minutes) } \\
\cline { 2 - 6 } & 1 & 2 & 3 & 4 & 5 \\
\hline$\% \mathrm{r}_{\text {(average) }}$ & 17.1 & 47.2 & 76.6 & 91.1 & 92.5 \\
$\mathrm{STD}( \pm)$ & 1.2 & 1.8 & 1.3 & 0.8 & 0.5 \\
\hline
\end{tabular}

\subsection{Effect of Initial $p H$}

To study the effect of $\mathrm{pH}$, the initial ammonia concentration $\left(\mathrm{C}_{\mathrm{i}}\right)$ and the microwave radiation time $(\mathrm{t})$ were fixed at specific values while $\mathrm{pH}$ was varied to the values 9,10 , and 11 . The general observed trend was that ammonia removal rate increased with the increase of $\mathrm{pH}$ as illustrated by Figure 4. For example, when the $\mathrm{pH}$ was 9 and $\mathrm{C}_{\mathrm{i}}$ was $100 \mathrm{mgNH}_{3}-\mathrm{N} / 1$ and after 4 minutes of radiation, the residual ammonia concentration (C) was $67 \mathrm{mg}$ $\mathrm{NH}_{3}-\mathrm{N} / 1$ (33\% removal) while it was reduced to $35 \mathrm{mg} \mathrm{NH}-\mathrm{N} / 1$ (65\% removal) and $9 \mathrm{mgNH}_{3}-\mathrm{N} / \mathrm{l}$ ( $91 \%$ removal) when the $\mathrm{pH}$ was increased to 10 , and 11, respectively. So there was a considerable increase of ammonia removal efficiency per each additional $\mathrm{pH}$ unit. Similar results were observed for all $\mathrm{C}_{\mathrm{i}}$ values tested in this experiment 
(i.e. $25,40,55,70,85$, and $\left.100 \mathrm{mg} \mathrm{NH} \mathrm{NH}_{3} \mathrm{~N} / \mathrm{l}\right)$ and for all radiation times in the range of 1 to 5 minutes. In all cases, the highest removal rates were achieved at a $\mathrm{pH}$ value of 11 compared to $\mathrm{pH}$ values of 10 and 9.

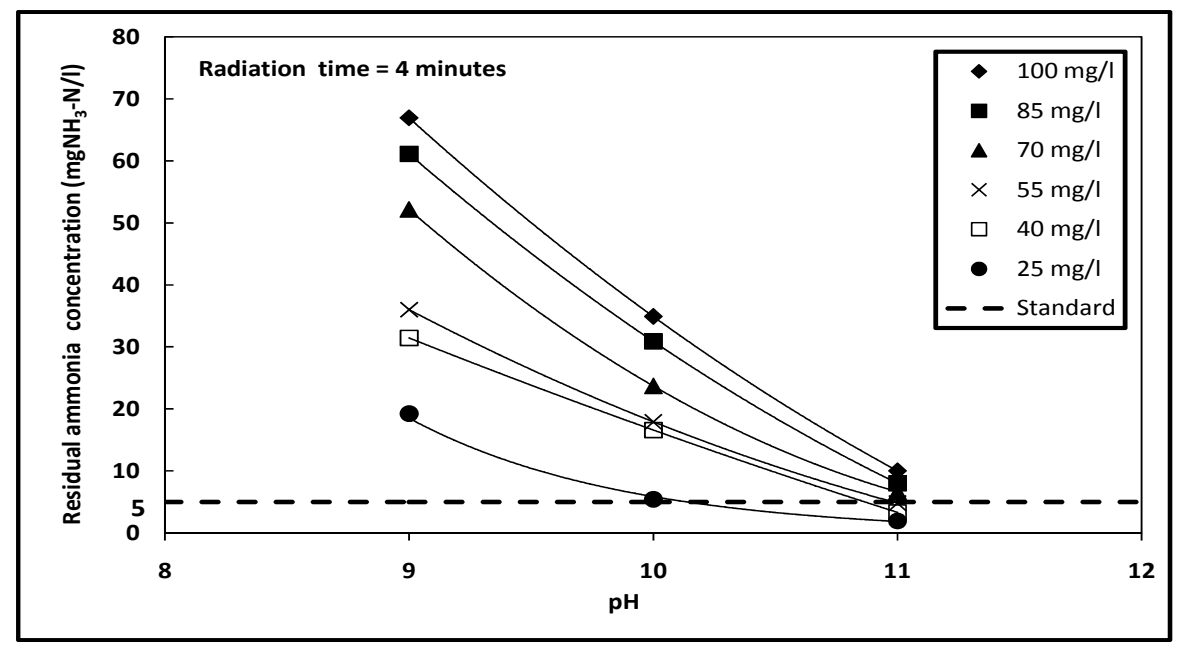

Figure 4. Effect of $\mathrm{pH}$ on ammonia residual $(\mathrm{MW}$ radiation time $=4)$

Lin et al. (2009) achieved 98\% ammonia removal from industrial wastewater with $\mathrm{pH} 11$ and after 3 min of radiation. In the Lin et al. (2009) work, the steady state removal percent of $98 \%$ was achieved in a shorter time ( 3 minutes versus 4 minute in this research). This is attributed to the higher microwaves' power input that they used (750 W versus $700 \mathrm{~W}$ in this research). Moreover, Lin et al. (2009) achieved higher steady state ammonia removal efficiency at a $\mathrm{pH}$ of 11 compared to the efficiency achieved in this work ( $98 \%$ versus $91 \%)$. This may be attributed to the higher initial concentration range that they worked with (in the range of 500-12000 mg $\mathrm{NH}_{3}-\mathrm{N} / \mathrm{l}$ ) compared to the low initial concentrations dealt with in this research (in the range of 25 to $100 \mathrm{mg}$ $\mathrm{NH}_{3}-\mathrm{N} / \mathrm{l}$ ). This may be attributed to the higher ammonia mass transfer rate resulting from higher driving force created by the high difference between initial and final ammonia concentrations (i.e. $\mathrm{C}_{\mathrm{i}}-\mathrm{C}$ ). For example, the driving force in Lin et al. (2009) work with a $\mathrm{C}_{\mathrm{i}}$ value of $12000 \mathrm{mg} \mathrm{NH}_{3}-\mathrm{N} / 1$ and a $\mathrm{C}$ value of $473 \mathrm{mgNH}_{3}-\mathrm{N} / 1$ was $11563 \mathrm{mg} \mathrm{NH} \mathrm{N}_{3} \mathrm{~N} / \mathrm{l}$, while the maximum driving force in this research was $91 \mathrm{mg} \mathrm{NH}_{3}-\mathrm{N} / 1 \mathrm{C}_{\mathrm{i}}=100 \mathrm{mg}$ $\left.\mathrm{NH}_{3}-\mathrm{N} / 1, \quad \mathrm{C}=9 \mathrm{mg} \mathrm{NH}-\mathrm{N} / \mathrm{l}\right)$. So it can be concluded that the ammonia removal characteristic at lower concentrations as those existing in municipal wastewater (in the range 25 to $100 \mathrm{mg} \mathrm{NH}$ - $\mathrm{N} / \mathrm{l}$ ) are different from the removal characteristic at higher concentrations as those found in industrial wastewater (up to $12000 \mathrm{mg}$ $\left.\mathrm{NH}_{3}-\mathrm{N} / \mathrm{l}\right)$.

The increased ammonia removal rate with the increase of $\mathrm{pH}$ value is attributed to the increase of the concentration of $\mathrm{NH}_{3}$, the unionized volatilizing form of ammonia. In basic solution, non-volatile $\mathrm{NH}_{4}{ }^{+}$converts to volatile $\mathrm{NH}_{3}$. The equilibrium equation of these two ammonia species is:

$$
\mathrm{NH}_{3}+\mathrm{H}_{2} \mathrm{O} \leftrightarrow \mathrm{NH}_{4}^{+}+\mathrm{OH}^{-}
$$

When the percentage of the volatile $\mathrm{NH}_{3}$ increases, the efficiency of ammonia removal by heating increases. The percent of volatile $\mathrm{NH}_{3}$ in solution is given by the following formula (USEPA, 1999b):

$$
\% \text { volatile } \mathrm{NH}_{3}=\frac{100}{1+10^{(p k a-p H)}}
$$

Where, pka is the ammonia dissociation coefficient.

Applying this formula at $\mathrm{pH}$ values of $9,10,11$ and 12 , and using a $p k a$ value of 9.34 (at $\mathrm{T}=22^{\circ} \mathrm{C}$, the initial temperature of solution before heating), the volatile $\mathrm{NH}_{3}$ percents in solution are calculated as 31,82 , 98 , and $99.7 \%$, respectively. So, the available volatile $\mathrm{NH}_{3}$ at $\mathrm{pH} 11$ is considerably higher than that at $\mathrm{pH}$ of 9 and 10 . This explains the higher ammonia removal percents at a $\mathrm{pH}$ of 11 compared to that at $\mathrm{pH}$ values of 9 and 11. It is also understood from the formula that increasing $\mathrm{pH}$ from 11 to 12 did not add a significant increase on the available volatile $\mathrm{NH}_{3}$ percent (increased from $98 \%$ to $99.7 \%$ only). Hence, increasing the $\mathrm{pH}$ from 11 to 12 is not economically justified since this will require the addition of significant amount of alkaline such as $\mathrm{NaOH}$ to the solution while not adding significant improvement on the removal efficiency of ammonia. Based on that, $\mathrm{pH}$ 
11 is suggested to be the optimum $\mathrm{pH}$ value for removing ammonia from wastewater.

\subsection{Effect of Radiation Time}

To study the radiation time effect, the initial $\mathrm{pH}$ value and the initial ammonia concentration were fixed at specific values while the value of radiation time was increased in the range of 1 to 5 minutes. The general observed trend was that ammonia concentration decreased nonlinearly with the increase of radiation time as illustrated by Figures 5, 6, and 7. For example, as shown in Figure 7, when the initial $\mathrm{pH}$ was fixed at 11, and the initial ammonia concentration was fixed at $55 \mathrm{mg} \mathrm{NH}_{3}-\mathrm{N} / \mathrm{l}$, the ammonia concentration decreased to $36 \mathrm{mg}$ $\mathrm{NH}_{3}-\mathrm{N} / 1$ after1 minute of radiation while it decreased to $4.9 \mathrm{mg} \mathrm{NH}_{3}-\mathrm{N} / 1$ after 4 minutes. It is interpreted from these figures that the relation between the residual ammonia concentration $(\mathrm{C})$ and the $\mathrm{MW}$ radiation time $(\mathrm{t})$ can be modeled by a third degree polynomial formula as the following:

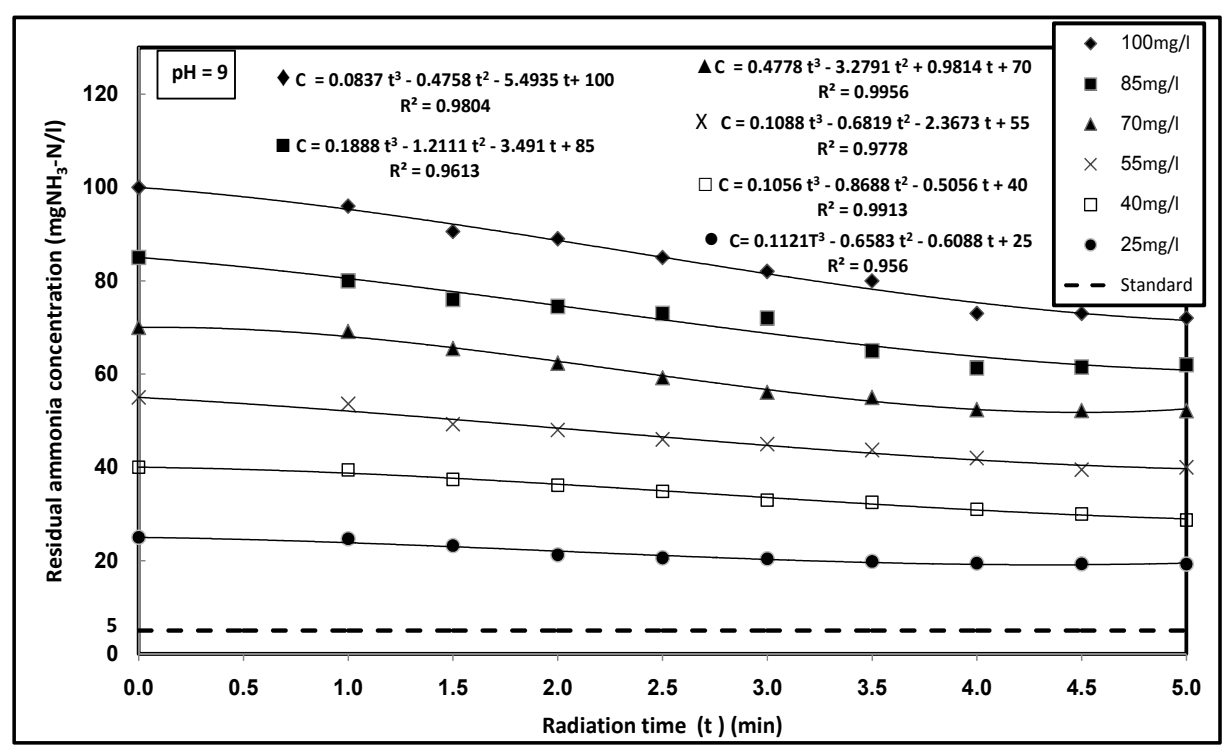

Figure 5. Effect of microwave radiation time on ammonia nitrogen removal $(\mathrm{pH}=9)$

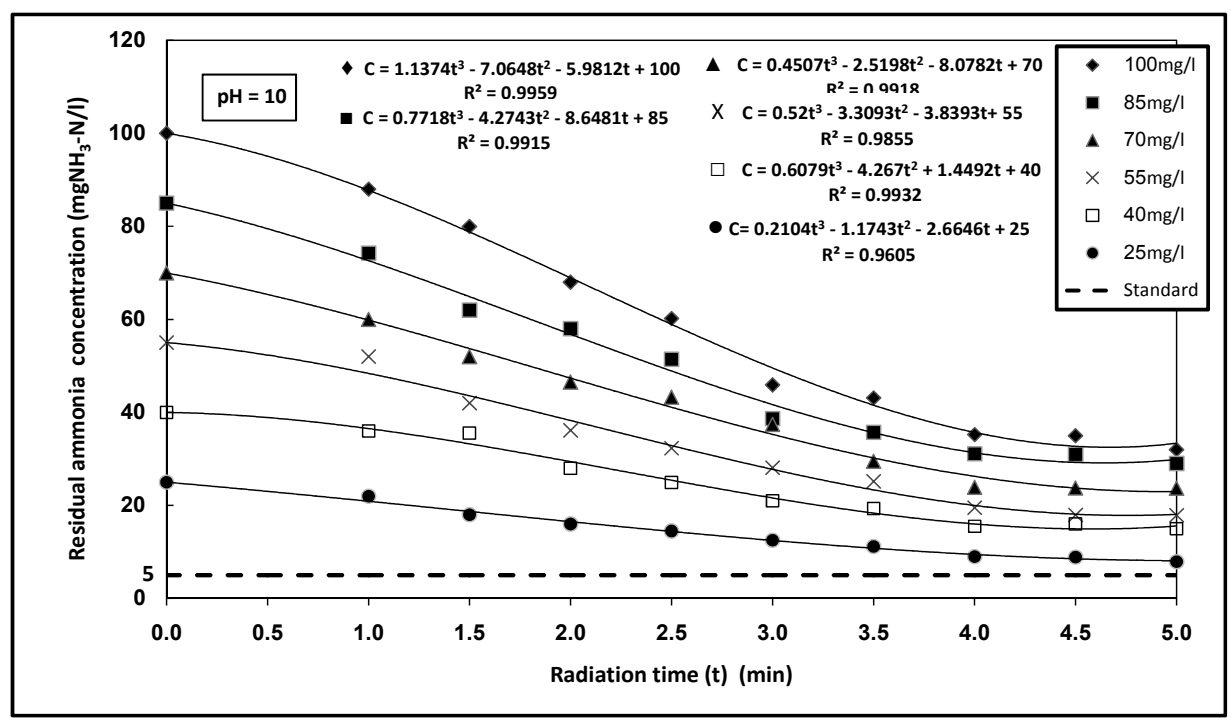

Figure 6. Effect of radiation time on of ammonia nitrogen removal $(\mathrm{pH}=10)$ 


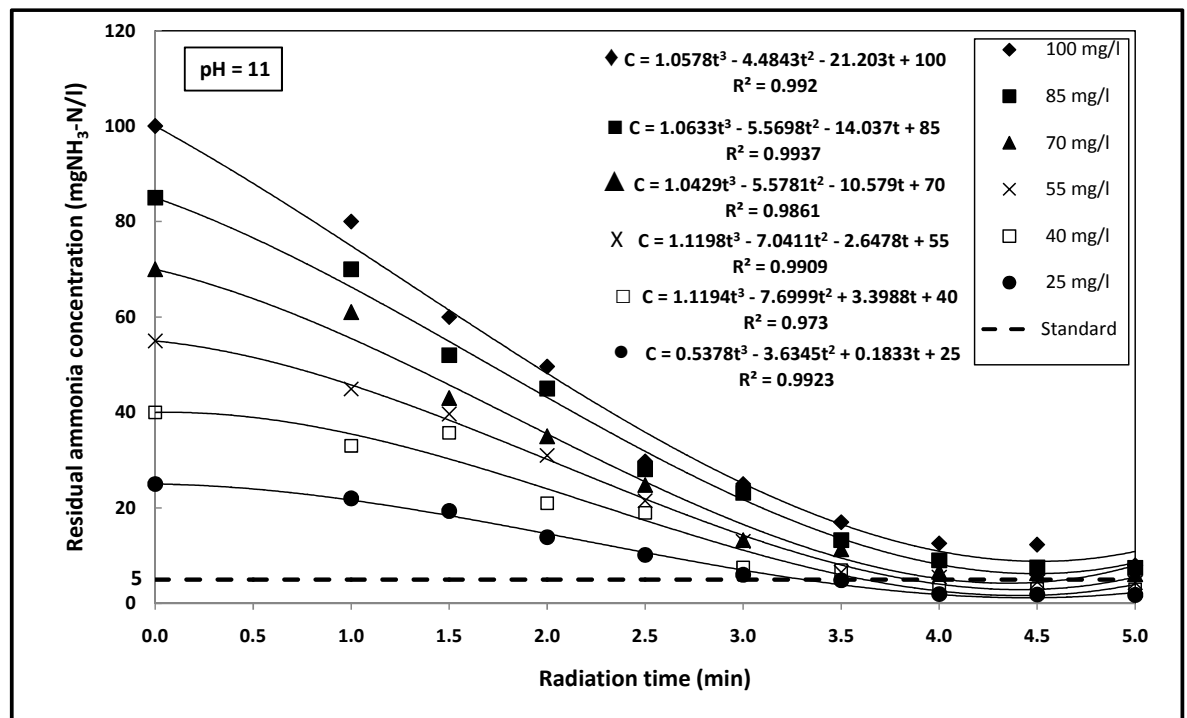

Figure 7. Effect of radiation time on ammonia nitrogen removal $(\mathrm{pH}=11)$

$$
C=K t^{3}-L t^{2} \pm M t+C_{i}
$$

Where,

$\mathrm{C}_{\mathrm{i}}=$ initial ammonia concentration, $\mathrm{mg} \mathrm{NH}_{4}-\mathrm{N} / 1$.

$\mathrm{K}, \mathrm{L}, \mathrm{M}=$ constant coefficients.

The polynomial formulae of each $\mathrm{pH}$ value and ammonia initial concentration are illustrated on Figures 5, 6 and 7. The values of the coefficients $\mathrm{K}, \mathrm{L}$ and $\mathrm{M}$ depend on $\mathrm{pH}$ and initial ammonia concentration. These formulae are valid for radiation time (t) in the range of 1 to 5 minutes and for initial ammonia concentration $\left(\mathrm{C}_{\mathrm{i}}\right)$ in the range of 25 to $100 \mathrm{mg} \mathrm{NH}_{3}-\mathrm{N} / \mathrm{l}$.

It is also interpreted from the data that no significant reduction of ammonia concentration was achieved when the radiation time was increased beyond 4 minutes regardless of the $\mathrm{pH}$ value or the initial ammonia concentrations (Figures 5, 6, and 7). For example, as shown in Figure 7, for an initial ammonia concentration of $55 \mathrm{mg} \mathrm{NH}$ - $\mathrm{N} / \mathrm{l}$, the residual ammonia concentrations were $4.96,4.50$, and $4.35 \mathrm{mgNH}_{3}-\mathrm{N} / 1$ at radiation times of $4,4.5$ and 5 minutes, respectively. This indicates that a steady state residual ammonia concentration is achieved after 4 minutes of radiation. Consequently, it is concluded that the optimum radiation time for the removal of ammonia is 4 minutes for the $\mathrm{pH}$ range 9 to 11 and for initial ammonia concentrations in the range of 25 to $100 \mathrm{mg}$ $\mathrm{NH}_{3}-\mathrm{N} / 1$.

\section{Treatment of Real Wastewater}

In order to confirm the results obtained from the synthetic wastewater experiments, a similar experiment was applied on three real wastewater samples that were collected from the treated effluent of Gaza Wastewater Treatment Plant. The samples were collected in Nov. 17 ${ }^{\text {th }}$, Dec. $15^{\text {th }} 2011$ and Feb. $18^{\text {th }} 2012$. Table 2 presents the main characteristics of each sample.

Table 2. Characteristics of the real wastewater samples

\begin{tabular}{ccccccc}
\hline Sample \# & Collection date & $\mathrm{pH}$ & $\begin{array}{c}\mathrm{BOD}_{5} \\
\left(\mathrm{mgO}_{2} / \mathrm{L}\right)\end{array}$ & $\begin{array}{c}\mathrm{TSS} \\
(\mathrm{mg} / \mathrm{L})\end{array}$ & $\begin{array}{c}\mathrm{NH}_{3} \\
\left(\mathrm{mgNH}_{3}-\mathrm{N} / \mathrm{L}\right)\end{array}$ & $\begin{array}{l}\text { Fecal } \\
\text { Coliform } \\
\text { Cell/100 ml }\end{array}$ \\
\hline 1 & Nov. $17^{\text {th }}, 2011$ & 7.2 & 130 & 105 & 52.30 & 3500 \\
2 & Dec. $15^{\text {th }}, 2011$ & 7.5 & 90 & 75 & 67.50 & 2750 \\
3 & Feb. $18^{\text {th }}, 2012$ & 7.4 & 110 & 92 & 86.70 & 3230 \\
\hline
\end{tabular}


The samples were heated by microwave radiation in the range of 1 to 5 minutes at the optimum pH value of 11 as found in the experiments performed on synthetic wastewater. Figure 8 shows the results obtained from treating the real wastewater samples for ammonia removal. The general observed trend (as illustrated by Figure 8) was that ammonia concentration decreased nonlinearly with the increase of radiation time following a third degree polynomial regression model indicating a similar behavior to that observed with synthetic wastewater treatment. The steady state residual ammonia concentration (C) was attained after 4 minutes of radiation in good agreement with the synthetic wastewater samples results. Moreover, the ammonia removal efficiency was also similar to that obtained with synthetic wastewater as illustrated in table 3 . As shown in the table (at radiation of 4 min.), when the initial ammonia concentrations were 52.30, 67.50 and $86.70 \mathrm{mg} \mathrm{NH} \mathrm{N}_{3} \mathrm{~N} / \mathrm{l}$, the removal efficiencies were, $91.50,90.10$, and $91.1 \%$, respectively. The average removal efficiency $\left(\mathrm{r}_{\text {average }}\right)$ in this case is $90.9 \pm 0.7 \%$ which is comparable to the $\left(\mathrm{r}_{\text {average }}\right)$ value of the synthetic wastewater which was $91.10 \pm 0.8 \%(\mathrm{pH}$ $=11, \mathrm{t}=4$ minutes) as reported in Table 1 . The similar ammonia removal efficiencies indicate that other constituents in the treated wastewater effluent such as organic matter and suspended solids has no significant effect on the ammonia removal efficiency by MW radiation.

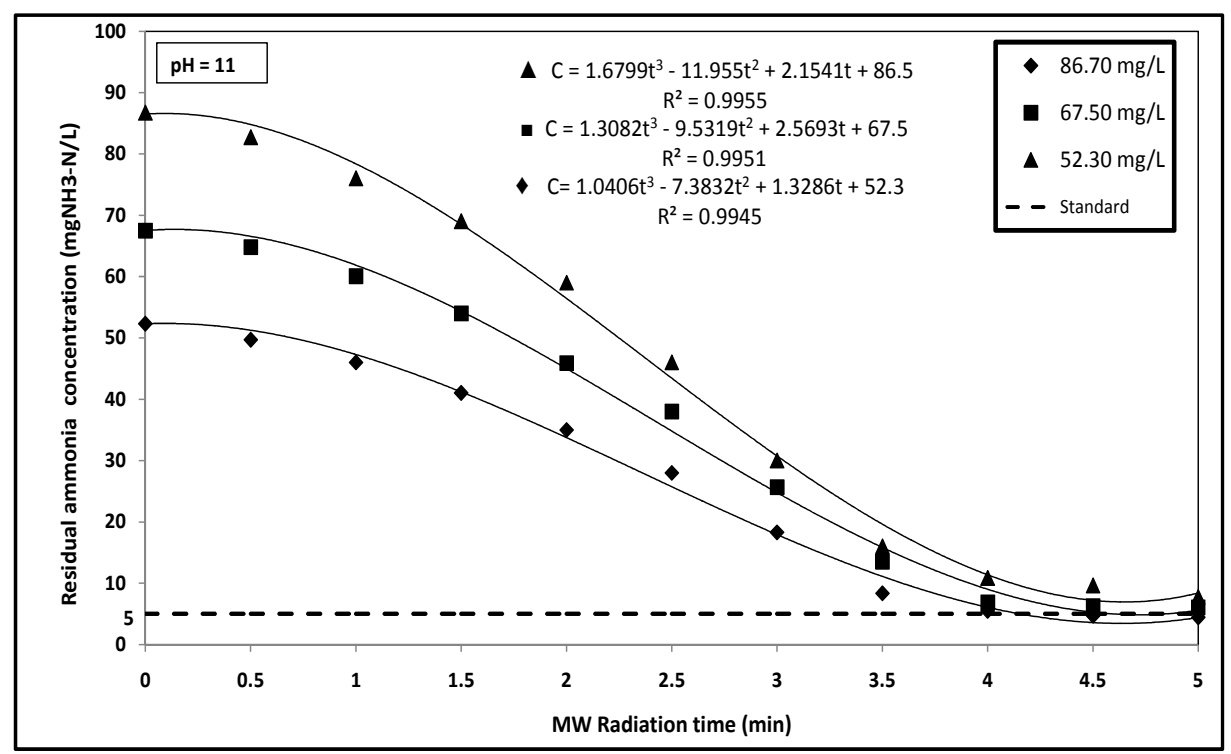

Figure 8. Residual ammonia in municipal wastewater versus $\mathrm{MW}$ radiation time $(\mathrm{pH}=11)$

Table 3. Final ammonia concentration after 4 min radiation

\begin{tabular}{ccc}
\hline Initial concentration $(\mathrm{mg} / \mathrm{l})$ & Final concentration $(\mathrm{after} 4 \mathrm{~min})(\mathrm{mg} / \mathrm{l})$ & Percentage of removal $(\mathrm{r} \%)$ \\
\hline 52.3 & 4.45 & 91.5 \\
67.5 & 6.08 & 90.1 \\
87.6 & 9.54 & 89.1 \\
\hline
\end{tabular}

\section{Conclusion}

This research was carried out to explore the ammonia nitrogen removal from municipal wastewater using MW energy. The effects of initial concentration, $\mathrm{pH}$, and radiation time, were investigated. Increasing radiation time together with $\mathrm{pH}$ had the most significant effect on ammonia nitrogen removal. Using $700 \mathrm{~W}$ MW energy, and $100 \mathrm{ml}$ synthetic wastewater samples, $91.10 \pm 0.8 \%$ ammonia nitrogen removal was achieved after 4 min radiation at a $\mathrm{pH}$ value of 11 . Similar ammonia nitrogen removal efficiency $(90.5 \pm 1.2 \%)$ was achieved with real municipal wastewater samples that were treated under the same conditions of $\mathrm{pH}$ and radiation time. Thus, the optimum ammonia removal from municipal wastewater by $\mathrm{MW}$ is achieved at a $\mathrm{pH}$ of 11 and radiation time of 4 minutes .The ammonia removal efficiency in the lower range concentration (25-50 $\left.\mathrm{mg} \mathrm{NH}_{3}-\mathrm{N} / \mathrm{l}\right)$ is found to be lower than the removal efficiency in the higher range (500-12000 $\left.\mathrm{mg} \mathrm{NH}_{3}-\mathrm{N} / \mathrm{l}\right)$. MW radiation is proved to be an effective alternative method for the removal of ammonia nitrogen from municipal wastewater. 


\section{Acknowledgement}

The authors would like to acknowledge and appreciate the complete financial support of this research by The Middle East Desalination Research Center (MEDRC).

\section{References}

APHA, AWWA, \& WEF. (1989). Standard Methods for the Examination of Water and Wastewater (17th ed.). Washington, DC: APHA.

Coastal Municipalities Water Utility. (2010). Wastewater lab tests results. Gaza.

Eskicioglu, C., Kennedy, K. J., \& Droste, R. L. (2009). Enhanced disinfection and methane production from sewage sludge by microwave irradiation. Desalination, 248(1-3), 279-285. http://dx.doi.org/10.1016/j.desal.2008.05.066

Guštin, S., \& Logar, R. (2011). Effect of pH, temperature and air flow rate on the continuous ammonia stripping of the anaerobic digestion effluent. Process Safety and Environmental Protection, 89(1), 61-66. http://dx.doi.org/10.1016/j.psep.2010.11.001

Holman, J. B., \& Wareham, D. G. (2005). COD, ammonia and dissolved oxygen time profiles in the simultaneous nitrification/denitrification process. Biochemical Engineering Journal, 22(2), 125-133. http://dx.doi.org/10.1016/j.bej.2004.09.001

Huang, H., Song, Q., Wang, W., Wu, S., \& Dai, J. (2012). Treatment of anaerobic digester effluents of nylon wastewater through chemical precipitation and a sequencing batch reactor process. Journal of Environmental Management, 101, 68-74. http://dx.doi.org/10.1016/j.jenvman.2011.12.035

JISM. (2006). Water-Reclaimed domestic wastewater. Technical Regulation, Jordanian Institution for Standards and Metrology, Jordan.

Jorgensen, T. C., \& Weatherley, L. R. (2003). Ammonia removal from wastewater by ion exchange in the presence of organic contaminants. Water Research, 37(8), 1723-1728. http://dx.doi.org/10.1016/S0043-1354(02)00571-7

Jothiramalingam, R., Lo, S., \& Chen, C. (2010). Effects of different additives with assistance of microwave heating for heavy metal stabilization in electronic industry sludge. Chemosphere, 78(5), 609-613. http://dx.doi.org/10.1016/j.chemosphere.2009.10.065

Lin, L., Yuan, S., Chen, J., Xu, Z., \& Lu, Z. (2009). Removal of ammonia nitrogen in wastewater by microwave radiation. Journal of Hazardous Materials, 161(2-3), 1063-1068. http://dx.doi.org/10.1016/j.jhazmat.2008.04.053

US Environmental Protection Agency (US EPA). (1999b). 1999 update of ambient water quality criteria for ammonia. EPA-822-R-99/014.

Yang, S., Wang, P., Yang, X., Wei, G., Zhang, W., \& Shan, L. (2009). A novel advanced oxidation process to degrade organic pollutants in wastewater: Microwave-activated persulfate oxidation. Journal of Environmental Sciences, 21(9), 1175-1180. http://dx.doi.org/10.1016/S1001-0742(08)62399-2

Zieliński, M., Zielińska, M., \& Dębowski, M. (2013). Application of microwave radiation to biofilm heating during wastewater treatment in trickling filters. Bioresource Technology, 127, $223-230$. http://dx.doi.org/10.1016/j.biortech.2012.09.102 